\title{
The Correlation Between Early Net Fluid Balance and The Clinical Outcomes of Patients Receiving Extracorporeal Cardiopulmonary Resuscitation
}

Original research

Keywords:

Posted Date: April 16th, 2021

DOI: https://doi.org/10.21203/rs.3.rs-131977/v2

License: (c) (i) This work is licensed under a Creative Commons Attribution 4.0 International License.

Read Full License 


\section{Abstract}

The authors have requested that this preprint be withdrawn due to erroneous posting.

\section{Full Text}

The authors have withdrawn this preprint from Research Square. 